\title{
Protective effects of low dose stabilized haemoglobin solution in experimental global ischaemia-reperfusion injury
}

\author{
L Zacchetti ${ }^{1,2^{*}}$, M Singer $^{2}$ \\ From ESICM LIVES 2015 \\ Berlin, Germany. 3-7 October 2015
}

\section{Introduction}

We previously reported that low doses of the purified stabilized bovine haemoglobin (EXP1) improved survival in a severe haemorrhage reperfusion model with beneficial effects on oxidative stress (unpublished data). We here report additional findings on a similar formulation, EXP2, at different doses using the same model of shock resuscitation.

\section{Methods}

Male Wistar rats (weight $306 \pm 15 \mathrm{~g}$ ) underwent arterial and central venous cannulation, tracheostomy, bladder catheterization and placement of a liver tissue $\mathrm{pO}_{2}$ sensor (Oxford Optronix, Oxford, UK). Controlled haemorrhage (45\% of estimated blood volume) was induced over 15 minutes and sustained shock (MAP target 40-45 $\mathrm{mmHg}$ ) was maintained for an additional 75 minutes. After crystalloid resuscitation, animals were randomized to receive a bolus injection of either Ringer's lactate (control) or EXP2 at 200, 400 or $900 \mathrm{mg} / \mathrm{kg}$ (New A Innovation Limited, Hong Kong). $700 \mathrm{mg} / \mathrm{kg}$ is approximately equivalent to a one-unit blood transfusion. Continuous i.v. fluid administration $(10 \mathrm{mg} / \mathrm{kg} / \mathrm{hr})$ was then infused for the following 4 hours. Echocardiography, blood gas analysis, blood pressure and liver tissue $\mathrm{pO}_{2}$ were measured pre- and post- insult, and then at hourly intervals. Two-way ANOVA with post-hoc t testing was used to detect statistically significant differences.

\section{Results}

Four-hour survival was $50 \%, 87.5 \%, 66.7 \%$ and $62.5 \%$ for the control, 200, 400 and $900 \mathrm{mg} / \mathrm{kg}$ groups, respectively.

'Università degli Studi di Milano, Dipartimento di Fisiopatologia Medico-

Chirurgica e dei Trapianti, Milano, Italy

Full list of author information is available at the end of the article
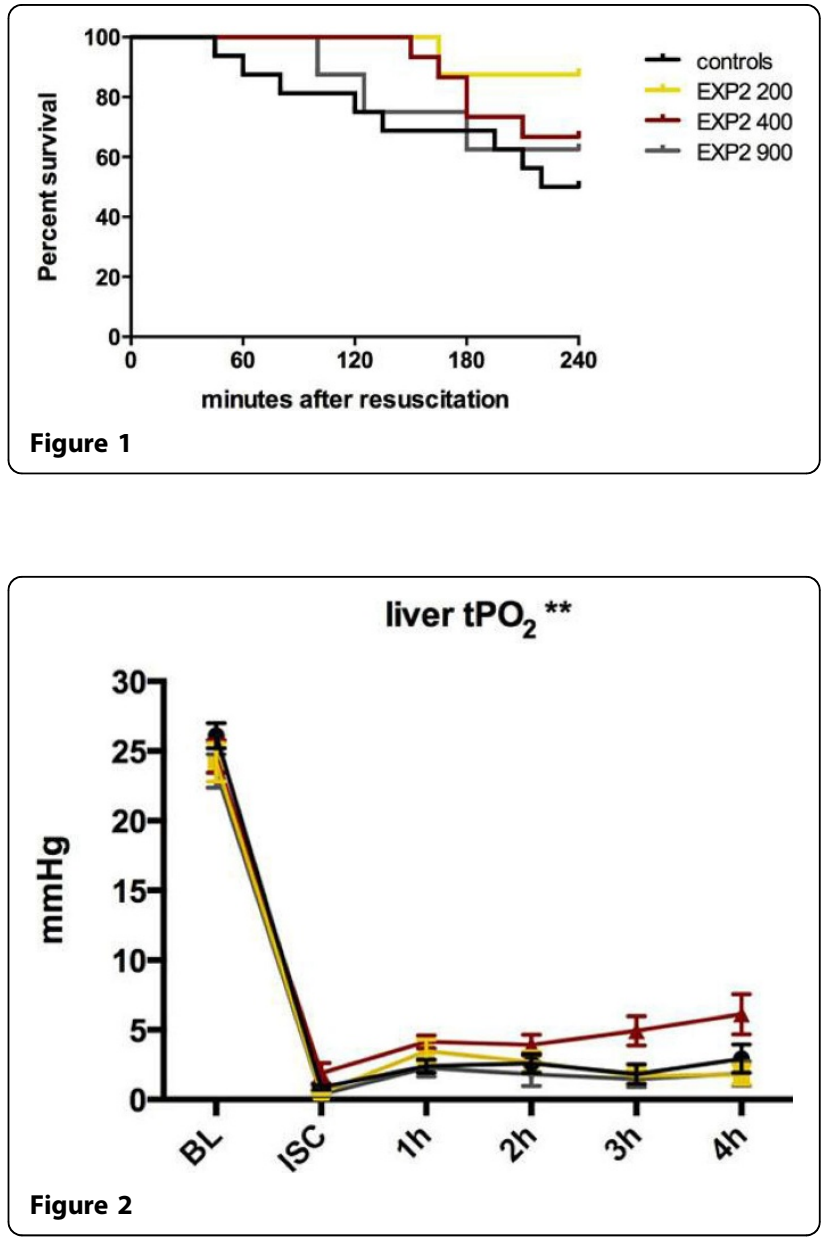

Small but significant changes were seen in plasma $\mathrm{Hb}$ levels, no changes were seen in lactate or oxygen delivery, while liver tissue $\mathrm{pO}_{2}$ increased only in the $400 \mathrm{mg} / \mathrm{kg}$ group. Notably, urine output improved at all EXP2 doses, 


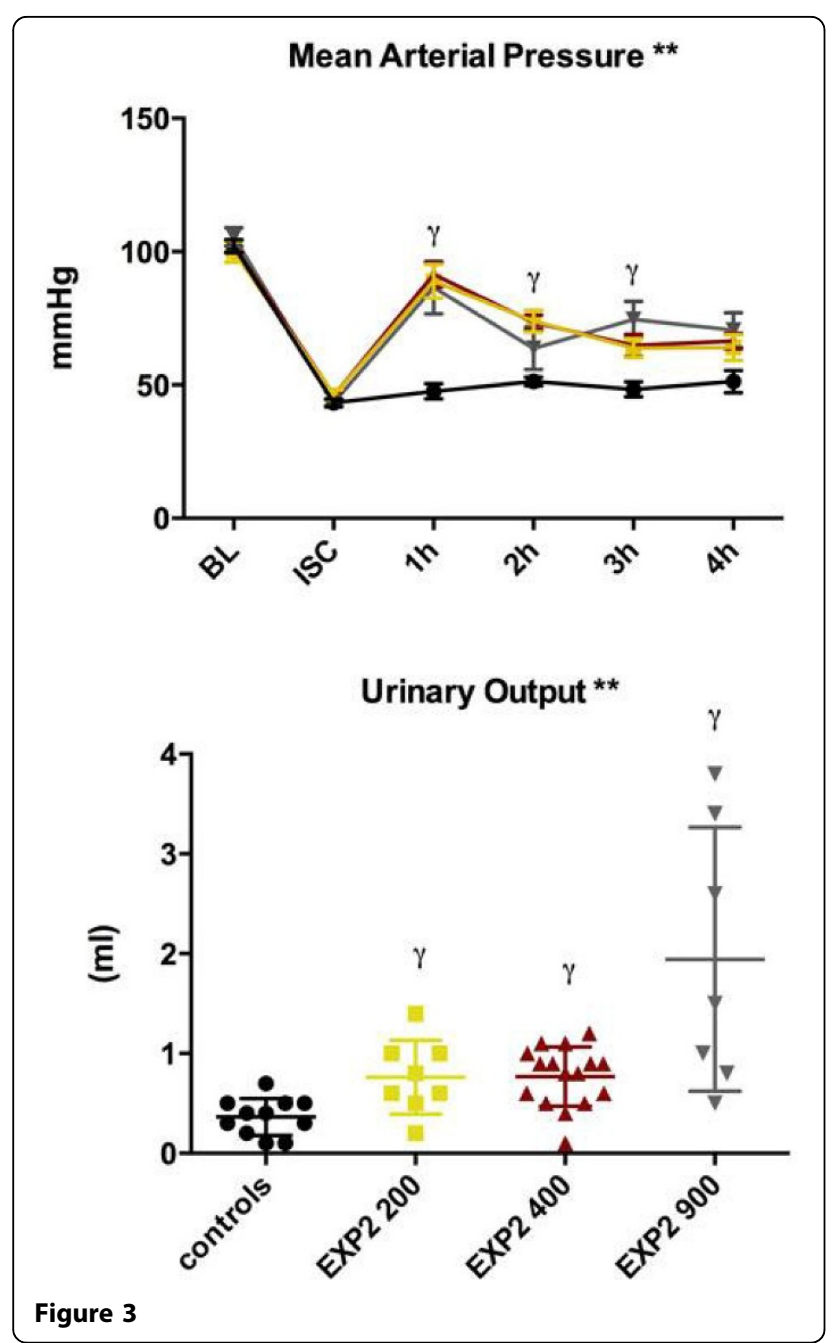

particularly in the $900 \mathrm{mg} / \mathrm{kg}$ group, though the pressor effect was identical for all doses of EXP2.

\section{Conclusions}

Low dose stabilized haemoglobin solution has potential utility in the treatment of global ischaemia-reperfusion injury though further work is needed to clarify optimal dose and mechanism(s) of action.

\section{Grant Acknowledgment}

New A Innovation Limited

\section{Authors' details}

'Università degli Studi di Milano, Dipartimento di Fisiopatologia MedicoChirurgica e dei Trapianti, Milano, Italy. ${ }^{2}$ University College London,

Bloomsbury Institute of Intensive Care Medicine, London, United Kingdom.

Published: 1 October 2015
doi:10.1186/2197-425X-3-S1-A912

Cite this article as: Zacchetti and Singer: Protective effects of low dose stabilized haemoglobin solution in experimental global ischaemiareperfusion injury. Intensive Care Medicine Experimental 2015 3(Suppl 1): A912.
Submit your manuscript to a SpringerOpen ${ }^{\mathcal{O}}$ journal and benefit from:

- Convenient online submission

- Rigorous peer review

- Immediate publication on acceptance

- Open access: articles freely available online

- High visibility within the field

- Retaining the copyright to your article

Submit your next manuscript at $>$ springeropen.com 